\section{SJESR}

Sir Syed Journal of Education \& Social Research

\title{
What Should We Learn from New Trends in Teacher Education
}

\author{
* Preeta Hinduja, MPhil Scholar (Corresponding Author) \\ ** Altaf Hussain, MPhil Scholar \\ *** Shahnaz Noor, MPhil Scholar
}

\begin{abstract}
This theoretical paper discusses the salient features of new trends in Teacher Education and their implications for teachers' learning in 21st century. With this, the paper represents Social Justice Approach, Master-Apprentice Approach, Teacher Identity Approach, Reflective practices Approach, Competence Approach and, Applied knowledge Approaches. In addition, the paper presents seven elements of effective Professional Development required being a $21^{\text {st }}$ century teacher as suggested by Darling-Hammond et al., (2017). Besides, the paper describes 'How teachers learn' suggested by Jones and Dexter (2014). It further discusses the questions and concerns that have been raised about these new trends. In addition, it highlights the issues faced by Pakistani teacher education program. Finally, the paper recommends what trend(s) Pakistani teacher Education should adapt that help teachers becoming prepare for $21^{\text {st }}$ century.
\end{abstract}

(ब) $(1)$

\section{Introduction}

In overall design features, Teacher Education (TE) globally bear much similitude to one another, such as students are required to take courses enabling them to learn foundation related to psychology, sociology, pedagogy. In general, TE programs offer those course that enhance the content knowledge of specific disciplines, pedagogical content knowledge that help to learn how to disseminate knowledge, principles of classroom management, knowledge regarding students and their characteristics, understanding of educational context, and also knowledge of educational aims and ends. With this, trainees are exposed to practice in different schools locating in surrounding. In spite of these resemblances, however, curriculum design and activities in teacher education highly depend upon the goals and aspirations of nations that are quite un-similar to each other (Shulman, 1987, p.8; Robinson \& Mogliacci 2019).

This article would explain key conceptions in the field of TE, relating to their assumptions and significance to be a teacher. Application of these conceptions is influenced by varied historical and geographical locations, thus adapted what is relevant. The underpinning assumptions and implication of each conception for the initial teacher education curricula design are then proposed.

There prevails huge literature e on related topic, however, this article is concise overview based on meta-description of academic publication. The paper primarily focus was to present the conceptions relevant to cross-disciplinary curriculum approaches rather than a specific subject discipline. The sources from 1990s are studies to present the contemporary viewpoints.

The theoretical understanding of these trends' concepts, principles and assumptions in the design of TE program would help educational stakeholders including educators and curriculum designers to contribute broadly (i.e. academically, professionally and politically) (Flores, 2017; Biesta, 2010; Korthagen et al., 2006). This review will offer rethinking on curriculum and pedagogy to improve the quality of Teacher Education Program within current socio-economic and political structure of Pakistan.

The representation of different trends will help developing a shared knowledge base, this may lead to build program coherence; recognising those areas that could have meaningful impacts on developing vision and positive attitude of teachers in their contexts. Even in this recent technological era, teachers' vision and attitude of 'good education' are key indicators of how they they integrate Information Communication Technology (ICT) in teaching-learning processes (Albion et al., 2015).

\footnotetext{
* Iqra University Karachi Email: preeta.19934@iqra.edu.pk

** Iqra University Karachi Email: mailaltafh@gmail.com

*** Iqra University Karachi Email: shahnazhoth@gmail.com
} 
Finally, this overview would also highlight a role of politics in education thus it would create space for transformation in Teacher Education. With this, the study contributes in the debate of ethics, aims and politics of education.

The following sections represent new trends in teacher education, their implication for teachers' learning in $21^{\text {st }}$ century and, what are related issues and challenges. This will commence with six major approaches in Teacher Education for instance, Social Justice Approach, MasterApprentice Approach, Teacher Identity Approach, Reflective practices Approach, Competence Approach and, Applied knowledge Approaches. After that, it will discuss on seven elements for effective Professional Development (PD) (Darling-Hammond et al., 2017) and, then describes "How teachers learn through formal, informal and independent modes of learning (Jones \& Dexter, 2014). It then ponders over the system-level obstacles that hinder the effectiveness of PD programs. Finally the paper shares the progress and issues in Pakistani context and concludes with recommendation for Pakistan teacher Education.

\section{Social Justice Approach}

Under the frame of Social Justice Approach, teacher education seeks to enable teacher students to understand relationship between schools and hierarchy/power. The aim is to developing an agent of change who address social equalities and contribute in building humane society. The underlying conceptions are emancipatory pedagogy, critical self-consciousness, social reconstruction, cultural responsiveness and the (de) coloniality (Christie \& McKinney, 2017 as cited in Robinson, 2019). The focus here is constant engagement in reflection on their own role and values being a teacher and thinking over how curriculum benefits or disadvantages different groups of learners. The role of teacher is promoting democracy in schools to transform the conditions of marginalized groups (based on race, class, language and power). This approach has been proven authentic in developing conceptual framework for understanding. Though, this approach is criticized for not suggesting any practical tool of teaching (McDonald, 2005, as cited in Whitcomb, 2010).

\section{Master Apprentice Approach}

In the Master Apprentice Approach, teacher students learn 'how to teach' by observing their master (experienced teacher/s) and, acquire different skills and strategies from their master. This is craft model based on practices and experiences avoiding disciplinary/theoretical knowledge. 'Learning to teach' model has been appreciated in Swiss teacher Education Program (Hascher, Cocard \& Moser, 2004) and in United Sates (Darling-Hammond, Hammerness, Grossman, Rust, \& Shulman (2005, p. 401). This approach is criticised for lack of theoretical integration in practice, this may cause lack of insight and reflection over sensitivities that may be currently invis ible yet prevalent (Viruru, 2005). Such teachers would not be able understand the problem adequately that otherwise could be examined and resolved with the help of theoretical foundation (Korthagen et al. (2006).

\section{Applied-Science approach}

In contrast with Master Apprentice Approach, Applied-Science approach renders its initial focus on theory, candidates learn subject knowledge before getting practical exposure and take professional decisions, this approach is useful in professionalizing teachers' work (Whitcomb, 2010). However it is argued that teachers under this approach work as mere technicians or theories implementers (Tuinamuana, 2007).

\section{Teacher Identity Approach}

Within the premises of Teacher Identity approach, the concept of Identity involves understanding of self within and outside the context such as those of school or classroom (Beauchamp \& Thomas, 2009, p. 178). Highlighting the notion of 'Identity agency' Ruohotie-Lyhty and Moate (2016) maintain that individuals are active agent in constructing the ir professional identities. This fosters wisdom (Whitcomb, 2010) and may develop them moral agent (Sockett, 2008) required to be a teacher. It is the role of teacher educator to get trainees alert about how the identities are developed with the exposure of different discourses, and if necessary teach them to deconstruct or resist such discourses. This approach is one of the challenging and argued for it bears scarce evidence in practical side (Rodgers \& Scott, 2008). This proposition requires teachers to understand the varied backgrounds of student teachers. For example a study from South Africa surfaces how candidates' schooling, qualification, expectations of assessment, readiness to share personal views poses much influence on reflection over their teaching (Rousseau, 2015). 


\section{Competence-based Approach}

Pantic and Wubbels (2010) denote Competence approach under which teachers need to acquire set of skills/professional competency in four domains (1) values and child nurturing, (2) Understanding of one's educational setup, (3) knowledge about subject, curriculum and pedagogy and (4) productive engagement in self-evaluation and professional development. The more comprehensive way of understanding teachers' competence is knowledge, skills, attitude and motives. The effective application of this model is evident in Serbia where teachers and teachers' educator realize their increased accountabilities and succeeded in meeting the demands of students (Pantic \& Wubbels 2010). The approach was also understood as performance based approach, became popularized in 1970s in United states and, 1980s in the United kingdom (Whitty \& Willmott, 1991). However, much skewed interpretation of this approach has brought forth the standardization of teacher education, educational outcomes and curriculum while ignoring the moral and evaluative dimension of teaching (Carr, 1993). While discarding the competence approach due to lack of theory of educational content, German Educationist Willbergh (2015) suggested teacher Education should aim to prepare teachers to understand the essence of educational content related to students' context and life-worlds. Mere Competence would not develop good teacher, instead good teaching involves judgment situated in time and space (Biesta, 2015, p. 5).

\section{Reflective Approaches}

Korthagen et al., (2006) highlighted Reflective Approaches help teachers continuously commute between theory and practice. This requires teachers to leap inside to aware one's own theories of teaching and motivations (Tuinamuana, 2007). The role of teacher educators is to set goal, means and ends of their performance (Zeichner, 2009); and simultaneously help them recognizing the problems and reset the goals that are crucial part of teaching (Loughran, 2002, 2006).

The aim of Reflective approach differed from other approaches (i.e-contributing to social change or improving teachers' technical profic iency) (Zeichner \& Liston, 2013). Referring to Dewey (1933) the authors suggest reflective practices would embed open-mindedness in teachers, cultivate sense of accountability and whole-heartedness, and allow individuals to examine own beliefs and assumptions on daily basis. While framing and reframing ones' work, teachers become capable to develop triangular relationship between theory, their experiences and practical wisdom (Lunenberg \& Korthagen, 2009).

\section{Elements of Effective PD}

Literature review highlights some more elements of PD. The research by Darling-Hammond et al. (2017) suggests seven elements for effective professional development required in $21^{\text {st }}$ century. These are Content specific knowledge; Active learning; peer collaboration; familiarization with the models of effective lessons; master trainer as an expert and coach; feedback and reflections and; adequate time duration.

Content focused PD directs its attention on teaching discipline-knowledge and pedagogical skills in the specific subject areas such as Mathematics, Science and Literacy. While active learning incorporates the artifacts, or interactive activities and/or related strategies that could develop contextualized professional learning. Teachers go beyond the traditional learning approaches that may/may not directly linked to classrooms or students but help improving content specific knowledge. Peer collaboration help to reflect and adjust classroom instructions and transform overall learning culture of class, school and district. While model lesson plans (written/video) or cases of effective teaching and observing model peers suggest insight of practicum. Expert coach share content based expertise and evident-based practices that cater to individual teachers' needs. Feedback and thoughtful reflection move teachers towards visionary professional practices. Sufficient time is also necessary in acquiring skills, learning, practicing, implementing and reflecting upon new observations that push individuals to bring changes in existing practices.

The research by Garet et al. (2001) has shown the empirical evidence of constructive effects of three components of PD (Content knowledge focus, active learning, and adherence with other learning activities). Their study's results endorsed teachers' self-reported improved knowledge and skills in their real classroom practices. Even so, with the positive effects of PD on teachers' knowledge/outcomes had lead to students' outdid achievement (Martin et al., 2010). 


\section{Learning through Formal, Informal and Independent modes}

21 st century teacher education program need to shift the focus from teacher development to teachers learning (Easton, 2008). One way to facilitate teachers ' learning is the movement towards establishing teachers' Professional Learning Communities (PLCs) rooted in group discussions (Hamos et al., 2009).

More than two decades ago, Bransford, Brown and Cocking (2000) perform analys is of more than thirty year studies on cognitive science researches. They found the role of effective environment in acquisition of quality learning. Environment should be designed as learner-centered, knowledgecentered, assessment centered, community centered.

Learner-centered exposure takes into account the elements such as individuals' knowledge and prior experience of learners, while knowledge-centered focus on conceptual understanding. Assessment-centered approach applies feedback, offer opportunity to reflect over leaning. While community centered learning environment allows individuals to share the common sense knowledge and develop the shared meaning and norms. Such environment can be framed with the combination of formal, informal and Independent mode of learning.

Teachers need to be provided an atmosphere based on research of 'How teachers' learn' suggested by Jones and Dexter (2014). According to their research it was surfaced that teachers learning occur in three inter-dependent modes: technology incorporated (1) formal, (2) informal and (3) Independent mode of learning. Elusiveness in any of the above mode especially informal and Independent typed would miss the acquisition of effective learning and predict potential loss in the investment over formal PD as well.

Each mode of learning has unique affordances and bear capabilities to meet each others' limitations. For instance to ensure learner-centered approach, formal PD assures the mandated skills aligned with teaching learning goals but, nevertheless the topics and meeting are scheduled by management not by learners this may cause misalignment of teachers' need with the scheduling. To fill this gap, informal PD and Independent learning activities allow learners to choose the content and learning process with the flexibility in participation time, but these may also prove limited in the assurance of participation in requisite activities.

For know ledge-centered environment, formal PD makes sure the guide by experts but prove elusive in addressing the whole group approach and content-specific learning, however that could be achieved via other modes but also dependent on how participants tackle. Moreover instructional approach in formal method may not be latest and richest that can otherwise be fulfilled in informal learning design with emerging technologies, but this is challenging to develop, use properly, and could sustain the self-selected tools.

Similarly, to attain the aspect of community-centered learning, formal set-up promotes collaboration within community of schools/organization. Such communication is accelerated with the development of self-selected community via informal platform; outside the schools' peers and globally. Additionally, fulfilling the need of assessment centered approach, formative feedback and reflective practices can be accomplished from all three types of exposure

Through formal PD organization, teachers come closer to each other that further lead them to informal learning. Informal discussions facilitate teachers to perform just-in-time requisites that were originated in formal PD activities. Similarly, Independent activities allow learners to acquire background knowledge or skills needed to maintain collaborations over formal and informal activities.

\section{Policy/System-level Obstacles}

Darling-Hammond et al. (2017) have noted that there are certain challenges in the achieving effectiveness of PD programs at schools and system level. The authors Darling-Hammond et al. (2017) report that many high poverty schools have not availability of technology for teachers and also inadequate financial resources (funding and required curriculum material) for proactive learning, this can inhibit the effectiveness of PD. Moreover the execution of PD activities requires to responsive to the need of educators, learners and their specific context.

Tooley and Connally (2016, as cited in Darling-Hammond et al., 2017) highlighted systemlevel's four major responsibilities in achieving effectiveness of PD. (1) Identifying PD needs from the responses by School Leaders, for that providing principals/Head teachers training to help them realize the areas of need; (2) Choosing effective approaches that could significantly raise students' achievement; (3) Implementation with quality and fide lity, this requires coach's expertise in specific 
subject areas and school's context, suggestions and creative approaches to the things try differently, feedback and deep observation; coach's authority to suggest further steps to follow; teachers' sense of accountability and time to follow the recommended steps have implications to gain outcomes; (4) Assess PD success/failure, system should analyze the quality and impact of PD by asking what and why questions and address the reported obstacles.

Researchers (Darling-Hammond et al., 2017) suggested that failing to align policies with stipulated practices would become a significant impediment. Policy can plan and set standards for PD in order to guide its design and evaluation, also policy can incentivize and support the PD imparted in educators. Administrators and policymakers can evaluate and adjust school schedules to raise professional learning opportunities for teachers including peer coaching, observations and collaborative planning. Management and administrators can conduct school surveys to indentify the needed area(s) of PD design desired by teachers. They can also develop mentor educators for other teachers.

Moreover, PD should capable teachers to benefit the students in term of students' improved literacy, direct their access to advanced coursework and create rather more positively the inclusive learning environment.

According to Darling-Hammond (2005), teachers in most of the countries including U.S, Japan, Taiwan, China, New Zealand, teachers spend 15 to 20 hours in the class while rest of the time went on refining their practices, In china for instance, teacher engaging with colleagues in curriculum design, observing each others' lesson, polishing lessons, exposing to study groups and participate in research on teaching. Japanese schools allocate 20 hours a week for teachers' collegial work, visits and planning of pedagogy.

\section{Teacher Education (TE) in Pakistan}

Pakistani teacher Education system is criticised for unproductive teaching-learning strategies, stereotypical attitude and beliefs of teachers, classrooms practices lacking the active participation of students and, missing of teachers' professional identity/professionalism (Gul \& Shah, 2019). Not only this, teachers' motivation, performance, competency, attitude and lower sense of accountability are also frequently reported issues (Messo \& Messa, 2017).This suggests the need of improvement in the Teacher Education Program (TEP) in Pakistan.

\section{Conclusion and Recommendation}

The above cited literature provides deeper understanding of new trends of Teacher Education and their impacts on teachers' beliefs, attitude and performance. On above grounds it is recommended that teacher educators and administrators need to plan spaces for teachers' learning based on integration of formal, informal and Independent learning opportunities following learner-centered, knowledgecentered and community centered approaches.

Moreover, the out-dated curriculum in Teacher Education is one of the potential inhibitors of teachers' growth and professionalism in Pakistan (Gul \& Shah). Curriculum needs to be revised with the adaption of six teacher learning approaches (Social Justice Approach, Master-Apprentice Approach, Teacher Identity Approach, Reflective practices Approach, Competence Approach and, applied knowledge approaches). This would stimulate self and social consciousness, engage the teachers in action researches and positively influence the decision making processes of teachers.

The cited review also suggests that effective implementation requires dealing $w$ ith challenges at both School level and System level. The follow-up assessment records at school-level and Policy implication at system-level are major components affecting the progress of the TE program. The coherence between school and system level would help overcome the challenges and achieving the effectiveness of TE programs.

\section{References}

Albion, P., Tondeur, J., Forkosh-Baruch, A. \& Peeraer, J. (2015). Teachers' professional development for ICT integration: Towards a reciprocal relationship between research and practice. Education and Information Technologies, 20(4), 655-673.

Beauchamp, C., \& Thomas, L. (2009). Understanding teacher identity: An overview of issues in the literature and implications for teacher education. Cambridge Journal of Education, 39(2), $175-189$.

Biesta, G. (2010). Good education in an age of measurement: Ethics, politics, democracy. Boulder, CO: Paradigm 
Biesta, G. (2015). How does a competent teacher become a good teacher? On judgement, wisdom and virtuosity in teaching and teacher education. John Wiley \& Sons.

Bransford, J.D., Brown, A.L. \& Cocking, R.R., eds. (2000). How People Learn: Brain, Mind, and Experience \& School. Washington, D.C., National Academy Press

Carr, D. (1993). Guidelines for teacher training: The competency model. Scottish Educational Review, 25(1), 17-25.

Christie, P., \& McKinney, C. (2017). Decoloniality and "Model C" schools: Ethos, language and the protests of 2016. Education as Change, 21(3), 1-21.

Darling-Hammond, L. (2005). Teaching as a profession: Lessons in teacher preparation and professional development. Phi delta kappan, 87(3), 237-240.

Darling-Hammond, L., Hammerness, K., Grossman, P., Rust, F., \& Shulman, L. S. (2005). The design of teacher education programmes. In L. Darling-Hammond \& J. Bransford (Eds.), Preparing teachers for a changing world (pp. 390-441). San Francisco, CA: JosseyBass.

Darling-Hammond, L., Hyler, M. E., \& Gardner, M. (2017). Effective teacher professional development. Learning Policy Institute. Retrieved from: https://learningpolicyinstitute.org

Dewey, J. (1933). How we think. A restatement of the relation of reflective thinking to the educative process. Boston, MA: D. C. Heath.

Easton, L. B. (2008). From professional development to professional learning. Phi Delta Kappan, 89(10), 755-761.

Flores, M. A. (2017). Practice, theory and research in initial teacher education: International perspectives. European Journal of Teacher Education, 40(3), 287-290.

Garet, M. S., Porter, A. C., Desimone, L., Birman, B. F., \& Yoon, S.Y. (2001). What makes professional development effective? Results from a national sample of teachers. American Educational Research Journal, 38(4), 915-945

Gul, S., \& Shah, D. (2019). Issues Confronted by Teachers' Education in Pakistan. International Journal of Academic Pedagogical Research (IJAPR), 3(1), 29-32.

Hamos, J. E., Bergin, K. B., Maki, D. P., Perez, L. C., Prival, J. T., Rainey, D. Y., . . . Vanderputten, E. (2009). Opening the classroom door: Professional learning communities in the math and science partnership program. Science Educator, 18(2), 14-24

Hascher, T., Cocard, Y., \& Moser, P. (2004). Forget about theory-practice is all? Student teachers' learning in practicum. Teachers and Teaching, 10(6), 623-637.

Jones, W. M., \& Dexter, S. (2014). How teachers learn: The roles of formal, informal, and independent learning. Educational Technology Research and Development, 62(3), 367-384.

Korthagen, F., Loughran, J., \& Russell, T. (2006). Developing fundamental principles for teacher education programs and practices. Teaching and Teacher Education, 22(8), 1020- 1041.

Loughran, J. (2002). Effective reflective practice: In search of meaning in learning about teaching. Journal of Teacher Education, 53(1), 33-43.

Loughran, J. (2006). Developing a pedagogy of teacher education: Understanding teaching and learning about teaching. London, U.K.; New York, NY: Routledge.

Lunenberg, M., \& Korthagen, F. (2009). Experience, theory, and practical wisdom in teaching and teacher education. Teachers and Teaching: Theory and Practice, 15(2), 225- 240.

Martin, W., Strother, S., Beglau, M., Bates, L., Reitzes, T., \& McMillan Culp, K. (2010). Connecting instructional technology professional development to teacher and student outcomes. Journal of research on technology in education, 43(1), 53-74.

McDonald, M. (2005). The integration of social justice in teacher education: Dimensions of prospective teachers' opportunities to learn. Journal of Teacher Education 56(5), 418- 435.

Messo, M. S., \& Messa, S. K. (2017). Study Of Teacher Preparation System In Pakistan And Japan, Finding Similarities/Dissimilarities And Suggest Improvement In The System. Grassroots, 50 (3). $102-124$

Pantic, N., \& Wubbels, T. (2010). Teacher competencies as a basis for teacher education - views of Serbian teachers and teacher educators. Teaching and Teacher Education, 26(3), 694-703.

Robinson, M., \& Mogliacci, R. J. (2019). Conceptions and Models of Teacher Education. In Oxford Research Encyclopedia of Education. DOI: 10.1093/acrefore/9780190264093.013.571

Rodgers, C., \& Scott, K. (2008). The development of the personal self and professional identity in learning to teach. In M. Cochran-Smith, S. Feiman-Nemser, D. J. McIntyre, \& K. E. Demers 
(Eds.), Handbook of research on teacher education: Enduring questions in changing context (pp. 732-755). New York, NY: Routledge.

Rousseau, N. (2015). The role of reflection in integrating theory and practice in foundation phase teacher education (Unpublished doctoral dissertation). Stellenbosch University, Stellenbosch, South Africa.

Ruohotie-Lyhty, M., \& Moate, J. (2016). Who and how? Preservice teachers as active agents developing professional identities. Teaching and Teacher Education, 55, 318-327.

Shulman, L. S. (1987). Knowledge and teaching: Foundations of the New Reform. Harvard Educational Review, 57(1), 1-22.

Sockett, H. (2008). The moral and epistemic purposes of teacher education. Handbook of research on teacher education. Enduring questions in changing contexts, 45-65.

Tooley, M., \& Connally, K. (2016). No panacea: Diagnosing what ails teacher professional development before reaching for remedies. Washington, DC: New America.

Tuinamuana, K. (2007). Reconstructing dominant paradigms of teacher education: Possibilities for pedagogical transformation in Fiji. Asia-Pacific Journal of Teacher Education, 35(2), 111127.

Viruru, R. (2005). Postcolonial theory and the practice of teacher education. In S. Ryan \& S. Grieshaber (Eds.), Practical transformations and transformational practices: Globalization, postmodernism, and early childhood education (Vol. 14, pp. 139-160). Bingley, U.K.: Emerald.

Whitcomb, J. A. (2010). Conceptions of teacher education. In P. Peterson, E. Baker, \& B. McGaw (Eds.), The international encyclopedia of education (Vol. 7, pp. 598-603). Oxford, U.K.: Elsevier.

Whitty, G., \& Willmott, E. (1991). Competence-based teacher education: Approaches and issues. Cambridge Journal of Education, 21(3), 309-318.

Willbergh, I. (2015). The problems of "competence" and alternatives from the Scandinavian perspective of bildung. Journal of Curriculum Studies, 47(3), 334-354.

Zeichner, K. M. (2009). Teacher education and the struggle for social justice. New York, NY; London, U.K.: Routledge.

Zeichner, K. M., \& Liston, D. P. (2013). Reflective teaching: An introduction. New York, NY: Routledge. 